\title{
Talking About Gender, Race and Class - Bringing Capitalism Back In: An Outline of a Preliminary Argument
}

\author{
John Acker
}

\section{Introduction}

Feminists have been talking about gender, race and class for at least 30 years, but their interconnectionsor intersectionality—are still problematic territory in feminist theoretical discourse, at least to me. I have been particularly concerned with three problems -

First, the concept of class has not been adequately reformulated to bring women's unpaid domestic labor into the understanding of class relations and capitalism, although many have argued that this labor is valuable to the economy and should be included in understanding class.

Second, how we conceptualize gender, race, and class affects how they can be seen to "intersect." Are gender, race, and class aspects of individual identity, processes involved in intra-group or inter-organizational relations, systems or regimes of inequality? Or all three? If we see these abstractions as systems, how do systems intersect?

Third, capitalist relations are the obvious context in which gender, race, and class processes occur, but capitalism is part of a shadowy background, not the foreground in many-not all-discussions.

I deal with these issues by proposing that we reconceptualize "economy" and think about class and capitalism as gendered and racialized.

I then use the resulting perspective on gendered and racialized class to briefly examine the contemporary crisis in care, work/family balance, or, more broadly, a crisis in social reproduction.

\section{The "Economy", Gendered and Racialized Class, and Capitalism.}

Economic Activity—can be defined as interdependent processes of provisioning, providing what is socially defined as necessary to sustain life and ensure individual and community survival. (Julie Nelson 1993)

Includes production, social reproduction, and distribution — paid and unpaid. Allows recognition of self-provisioning and other noncapitalist forms of provisioning. This concept also allows the inclusion of unpaid activities of caring for others, educating, and preparing workers for the next day of work and raising the next generation of workers and citizens. (Elson 2000)[1]

Class - unequal power and control over and access to means of provisioning. Practices that produce, maintain or cope with those inequalities. Class relations are gendered and racialized. Class practices are diverse, emerge in political as well as economic processes. Example: women on welfare who have no control over and minimal access 
to the means of provisioning. They put together resources for their families from different sources, such as welfare benefits, paid work, money from friends and family, and odd jobs. Historically changing class power relations are differentiated by gender and race.

Capitalism-the present form of organizing much provisioning activity. Unequal power and control result from this capitalist organization (of course, not the only way to look at capitalism.) We can assess the economy in terms of how well it does in provisioning the population. Rather than looking at GNP or economic growth, the first question might be about adequate provisioning at the bottom or adequate support for care.

\section{Gendered Contradictions of Capitalism}

The aims and ways of organizing of capitalist production and human reproduction are different and often contradictory.

- Primary aim of production is profit, not provisioning

- Primary aim of families and households is provisioning, preserving and enhancing life,

Contradictions are anchored in the gendered separation of production and households. Often racialized in U.S. Capitalist production decisions are based on what will sell, not necessarily on what is needed by families and households.

Contradictions are also anchored in commodification of labor (Polanyi 1947). Labor is bought only as needed, at the lowest price possible. When labor is not needed, it is not bought, as with any other commodity. When wages provide the primary means of access to provisioning, lack of demand for this commodity has calamitous consequences for ordinary people who depend on wages. As Polanyi argues, the commodification of labor, along with land and money, are necessary to the functioning of industrial capitalism.

\section{The Result: Non-responsibility of Capitalist Organizations}

- Nonresponsibility $=$ refusals or attempts to avoid meeting provisioning needs unless actions enhance private interests, profit, or accumulation of capital. This includes refusals to attend to the conditions of provisioning such as safety and quality of products.

- Legal status of corporations in many states confirms non-responsibility. Primary obligation to stockholders is written into law. With the legal status of individuals, corporations claim privacy rights in regard to information about many of their actions.

Claims to nonresponsibility are endemic, Responses to demands from employees, customers, social movements, communities, governments for:

- $\quad$ Living wages, workplace safety, hours, benefits

- $\quad$ Affirmative Action, pay equity

- $\quad$ Paid, quality day care; paid family leave

- Environmental damage, community health

- Income support and replacement, adequate low-cost housing, health care

- $\quad$ Product quality and safety

Women and households are the fall back resources for provisioning-their unpaid work is devalued, partly because it does not result in money.

Corporations defend themselves, sometimes take positive action, support Corporate Social Responsibility, arguing that there is a business case for responsibility. Corporations defend themselves:

- To secure or retain a labor supply

- To retain or gain customers 
- $\quad$ To reduce civil disorder

- To maintain or achieve legitimacy

- To avoid legal challenges to their policies

Question seldom asked: how those doing unpaid caring work will be provisioned. This work is essential to the reproduction of the society, to the family and household, and to employing organizations.

Past solutions, now disappearing:

The male provider - myth or reality? — probably existed only for middle and upper class white families until the New Deal and end of WW II when a "family wage" was achieved through labor union bargaining in some sectors.

The welfare state was always minimal in the United States. Its development was limited by the politics of race and liberal/conservative capitalism (Quadagno 1994). A long war on labor also limited the kind of social democratic developments that supported the welfare state in other countries (e.g. Piven and Cloward 1994).

\section{The Nonresponsibility of U.S. Capitalism and the Care Crisis}

Care crises result from the nonresponsibility of capitalist organizations, the underlying relations that produce non-responsibility, and the victories of neo-liberalism that opposes government solutions.

Care crises are gendered and racialized class issues that now are crossing class line. Care problems affect middle class and working class mothers and fathers, both single and partnered, who have jobs. The present impact on middle class families may be the reason that the crisis is visible to white middle class observers now. Observers from other locations might say that a care crisis has always faced poor African American families. Another less advantaged group, poor two parent families and single poor mothers often suffer a more aggravated crisis because they lack the basic income to support their families, often because of racial/ethnic discrimination. Moreover, millions of poor people throughout the world are coping with not only a care crisis, but also a broader crisis in social reproduction. These are related, but not identical problems:

"Care" stands for the mostly unpaid labor of nurturing and caring for children and the ill elderly, usually but not always in the family and in the home. Care giving has a lack of fit with the demands of paid work, organized on the model of a worker with no such obligations.

"Work/family balance" is a solution to the care problem-it has to do with care-giving supports-family leave, good quality day care, time flexibility — that allow women and men to both work and care for their children, themselves and for parents or others who may be ill.

"Social reproduction" is a broader concept that can include replenishing and preparing workers for the next day, creating the next generation of citizens and workers, having available the resources to do these things, including health care, affordable housing, a basic reliable income, affordable education, public safety, and the provision of life necessities such as clean water and food. A crisis in social reproduction exists for some sectors of the U.S. population, as well as for large groups in many other countries.

Restructuring of the national and global economy undermines old solutions to the problem of provisioning.

Jobs for women open up and women go to work, substituting their paid labor for unpaid labor, that is still done, but under greater pressure. Work and other demands increase. Men's wages are flat or falling-"family wage" is gone for most. No alternative supports are developed, overwhelmingly because of capitalist neo-liberal opposition. Result-escalation of the care crisis.

Neoliberalism provides ideological support for nonresponsibility and for undermining old supports. Down-sizing and off-shoring jobs, privatizing and downsizing government supports. Destruction of the social safety-net. Structural readjustment imposed on many countries. The idea that care is a private, individual matter. The imperative that everyone must work for wages. 


\section{Welfare State Solutions Remain Strong in Other Wealthy Countries.}

Political processes make crass nonresponsibility and destruction of supports for social reproduction very difficult to implement. Nevertheless, strong pressures from corporations and neo-liberal economists push for reducing social benefits in EU countries, in the name of flexibility, competitiveness, and low unemployment.

\section{Possible solutions}

- Organize to exert political and social pressure-make care a social, not an individual problem.

- $\quad$ Strengthen the social safety net

- Institute basic income support, such as a citizen's income

- Legislate mandatory and paid family leave, flexible work schedules, government support or employer supported day care.

- Raise political questions about the viability of an economy in which the organizations that control the means of provisioning have no responsibility for the provisioning of the population

\section{Conclusion:}

Many solutions to the care crisis or the crisis in social reproduction are possible, but all involve restraining the nonresponsibility of capitalism.

\section{Endnotes}

1. This is, of course, an old argument made by socialist

feminists beginning in the 1970s.).

\section{References}

Nelson, Julie A. 1993. "The Study of Choice or the Study of Polanyi, Karl. 1957. The Great Transformation. Boston:Beacon Provisioning? Gender and the Definition of Economics." In Press.

_Beyond Economic Man: Feminist Theory and Economics, Quadagno, Jill. 1994. The Color of Welfare: How Racism edited by Marianne A. Ferber and Julie A. Nelson. Undermined the War on Poverty. New York:Oxford Chicago:University of Chicago Press.

Piven, Frances Fox and Richard Cloward. 1994. Regulating the

University Press.

Poor. New York:Random House. 